\title{
The Effects Of Cigarette Smoking On The Serum Levels Of Some Antioxidants (Vitamin C And E ) Amongst Male Smokers In Levels In College Of Health Sciences, Nnamdi Azikiwe University, Nnewi Campus, Anambra State.
}

\author{
Okwara John Ekenedilichukwu', Ibe Chukwuemeka Solomon ${ }^{2}$ * Ogbodo Emmanuel Chukwuemeka ${ }^{2}$, \\ Analike Rosemary Adamma ${ }^{1}$, Onyegbule Onyema Athanatius ${ }^{1}$, Oguaka Victor Nwabunwanne, \\ Amah Akuma Kalu ${ }^{4}$, Mbaeri Timothy Uzoma ${ }^{5}$, Meludu Samuel Chukwuemeka ${ }^{2,3}$. \\ ${ }^{1}$ Department of Chemical Pathology, Faculty of Medicine, Nnamdi Azikiwe University, Nnewi Campus, \\ Anambra State, Nigeria; \\ ${ }^{2}$ Department of Medical Laboratory Science, Faculty of Health Sciences, Nnamdi Azikiwe University, \\ Nnewi Campus, Anambra State, Nigeria; \\ ${ }^{3}$ Department of Human Biochemistry, Faculty of Basic Medical Sciences, Nnamdi Azikiwe University, \\ Nnewi Campus, Anambra State, Nigeria; \\ ${ }^{4}$ Department of Physiology, College of Medicine, Imo State University, Owerri; \\ ${ }^{5}$ Department of Surgery, Faculty of Medicine, Nnamdi Azikiwe University, Nnewi Campus, Anambra State Nigeria. \\ *Corresponding Author's Email I.D: augustinee442@gmail.com
}

\begin{abstract}
Smoking has been identified as one of the major risk factors in human diseases such as atherosclerosis and several cancers. This study investigated the effect of smoking on vitamin $\mathrm{C}$ and $\mathrm{E}$ levels in male cigarette smokers in College of Health Sciences, Nnamdi Azikiwe University, Nnewi Campus, Anambra State. A total of 100 subjects comprising of (50 smokers and controls) each were recruited for the study. A well structured questionnaire was used in obtaining the demographic and anthropometric data as well as dietary pattern of subjects. Thereafter, $5 \mathrm{mls}$ of blood sample was collected from subjects and used for the evaluation biochemical parameters. Biochemical parameters (vitamin $\mathrm{C}$ and $\mathrm{E}$ levels) were estimated using standard methods and results subjected to statistical analysis using student t-test and Pearson $\mathrm{r}$ correlation. The results show a significant decrease in the mean serum levels of Vitamins $C(0.82 \pm 0.33$ vs $1.49 \pm 0.25$; $\mathrm{p}=0.000)$ and $\mathrm{E}(12.36 \pm 1.61$ vs15.61 $\pm 1.91 ; \mathrm{p}=0.000)$ in smokers compared with non smokers respectively. More so, there was a significant positive correlation between BMI and serum level of Vitamin $\mathrm{C}(\mathrm{r}=0.345$; $\mathrm{P}=0.014)$ and $\mathrm{E}(\mathrm{r}=0.187 ; \mathrm{P}=0.024)$ in cigarette smokers. In conclusion, the study revealed the deleterious effects of cigarette smoking on serum levels of vitamins $\mathrm{C}$ and $\mathrm{E}$ in smokers. Hence, there is need for proper dietary management in patients.
\end{abstract}

Key Words: Smoking, Male Cigarette smokers, Vitamin C, Vitamin E, Anthropometric data, Nnewi Campus.

\section{Introduction}

Smoking has been identified as one of the major risk factors in human diseases such as atherosclerosis and several cancers (Doll et al., 1994; Mosca et al., 1997), yet approximately one third of the Western World's adult population continues to smoke (WHO Health for All Database, 2000).

The mechanism most often cited as the cause of smoking-related disorders is oxidant damage from free radicals generated in cigarette smoke and from reactive oxidants created by smoke-induced activation of the inflammatory immune system (Pryor and Stone, 1993). Vitamin C (ascorbic acid) is an effective free radical scavenger and is among the strongest determinants of plasma total antioxidant defense (Lykkesfeldt et al., 2000). It is well established that cigarette use compromises vitamin C status in active smokers. The 
observation that vitamin $\mathrm{C}$ excretion in smokers was lower than in nonsmokers was first made over 60 y ago (Strauss and Scheer, 1939), and it is now known that metabolic turnover of vitamin C in smokers is approximately double that in nonsmokers (Cross et al., 1999).Because cigarette smoke has been shown to result in increased oxidative stress as measured by a variety of biochemical markers, it has been speculated that increased consumption of fruits and vegetables rich in antioxidants or even specific antioxidant supplements could perhaps be particularly beneficial to smokers (Ames and Gold 1998; Ames and Wakimoto, 2002).

Indeed, numerous reports have shown that cigarette smokers have lower plasma concentrations of almost all low-molecular-weight antioxidants (Lykkesfeldt et al., 1997; Munro et al., 1997). This condition results from at least two factors, one of diet and one of smoking (Lykkesfeldt et al., 2000; Dietrich et al., 2003). Thus, because of the consumption of a diet containing more fat and less fruits and vegetables, smokers have a lower intake of a variety of phytonutrients, compared with nonsmokers (Zondervan et al., 1996; Dallongeville et al., 1998; Marangon et al., 1998a; Ma et al., 2000). However, in addition to dietary differences, it has been shown in studies correcting for dietary intakes of antioxidants, that in particular, vitamin $\mathrm{C}$ is further depleted by the smoke itself (Lykkesfeldt et al., 2000; Dietrich et al., 2003). Therefore, well-designed human clinical studies evaluating vitamins $\mathrm{C}$ and $\mathrm{E}$ utilization under conditions of oxidative stresses such as cigarette smoking are imperative. Hence, this study investigated the effect of smoking on vitamin $\mathrm{C}$ and $\mathrm{E}$ levels in male cigarette smokers in College of Health Sciences, Nnamdi Azikiwe University, Nnewi Campus, Anambra State, Nigeria.

\section{Materials and Methods \\ Study Area}

The study was carried out in Nnewi North Local Government Area of Anambra State, Nigeria. Research

\section{Design}

The research was a study designed to measure the level of vitamin $\mathrm{C}$ and $\mathrm{E}$ among smokers in Nnewi North, Anambra State, Nigeria. The protocol was explained to the participants and those who gave their informed consent were randomly recruited. The study population comprised of 100 adult male subjects aged between 18 to 45 years, divided into two groups as follows; Fifty (50) cigarette smokers as test subjects and Fifty (50) non- cigarette smokers used as control respectively. The anthropometric data and dietary pattern of the subjects were obtained using a well-structured questionnaire. Thereafter, $5 \mathrm{mls}$ of blood samples were collected from the subjects into plain containers and used for biochemical analysis. The serum vitamin $\mathrm{C}$ and E levels were estimated using standard methods as described by Omaye et al., 1979; and Jadoon et al., 2010, respectively.

\section{Ethical Consideration}

Ethical approval was sought and obtained from the Ethics Committee of Nnamdi Azikiwe University Teaching Hospital, Nnewi, Anambra State, Nigeria in accordance with the declaration of Helsinki on research involving human subjects (Snezana, 2001; Levine and Robert, 2006).

\section{Inclusion criteria and Exclusion Criteria}

All male cigarette smokers aged between 18 to 45 years were recruited whereas, Cigarette smokers under vitamins $\mathrm{C}$ and $\mathrm{E}$ supplements, Female smokers, Subjects with terminal disease as well as Cigarette smokers less than 18 years old were excluded from the study.

\section{Statistical method}

The result from this study was organized and subjected to statistical analysis using Statistical packages for social science (SPSS) version 20. Student t-test was used to compare differences between groups. $P<0.05$ was considered statistically significant.

\section{Result}

Table 1 result shows the descriptive statistics of the participants anthropometric involves in the study. The mean of the Age was (26.44 \pm 4.05$)$, and the range was between (18-45 years), the mean weight of the respondent was $(63.61 \pm 7.93)$, and the range was $(44-84 \mathrm{Kg})$, the mean height of the respondents was $(1.68 \pm 0.09)$ and the range was $\left(1.50-1.87 \mathrm{M}^{2}\right)$, and the BMI mean of the respondents was $(22.43 \pm 2.76)$, with the range being $\left(16.01-29.43 \mathrm{Kg} / \mathrm{M}^{2}\right)$.

Table1: Anthropometric Parameters of Respondents 


\begin{tabular}{lcrrr}
\hline VARIABLES & $\mathrm{N}$ & \multicolumn{1}{c}{ RANGE } & MEAN & \pm SD \\
& & & & \\
Age (Years) & 100 & $18.00-45.00$ & 26.44 & \pm 4.05 \\
Weight $(\mathrm{Kg})$ & 100 & $44.00-84.00$ & 63.61 & \pm 7.93 \\
Height $(\mathrm{M})$ & 100 & $1.50-1.87$ & 1.68 & \pm 0.09 \\
BMI $\left(\mathrm{Kg} / \mathrm{M}^{2}\right)$ & 100 & $16.01-29.43$ & 22.43 & \pm 2.76 \\
\hline
\end{tabular}

Table 2 shows the independent t-test analysis comparing the level of Vitamin C \& E level of Non-Smokers and Smokers. For the Vitamin $\mathrm{C}$ level, there was a significant decrease when comparing the Non-Smokers $(1.49 \pm 0.25)$ to the Smokers $(0.82 \pm 0.33), \mathrm{P}<0.05$. For the Vitamin E level, there was a significant decrease when comparing the Non-Smokers $(15.61 \pm 1.91)$ and Smokers (12.36 \pm 1.61$), \mathrm{P}<0.05$.

Table 2: The Levels Of Vitamin C And E Between Smokers And Non-Smokers Studied.

\begin{tabular}{llcrcc}
\hline & & & & & \\
& GROUPS & $\mathrm{N}$ & MEAN \pm SD & P-VALUE & T-Value \\
\hline Vitamin C & Non-Smokers & 50 & $1.49 \pm 0.25$ & $0.000^{*}$ & \\
& Smokers & 50 & $0.82 \pm 0.33$ & & -11.415 \\
Vitamin E & Non-Smokers & 50 & $15.61 \pm 1.91$ & $0.000^{*}$ & \\
& Smokers & 50 & $12.36 \pm 1.61$ & & -9.188 \\
\hline & *Statistically significant at $\mathbf{p}<\mathbf{0 . 0 5}$ & &
\end{tabular}

Result from Table 3 Showed an Insignificant negative correlation between age and Serum level of Vitamin $\mathrm{C}(\mathrm{r}=-0.016 ; \mathrm{P}=0.913)$ and $\mathrm{E}(\mathrm{r}=-0.108 ; \mathrm{P}=0.456)$. There was a significant positive correlation between $\mathrm{BMI}$ and Serum level of Vitamin $\mathrm{C}(\mathrm{r}=0.345 ; \mathrm{P}=0.014)$ and $\mathrm{E}(\mathrm{r}=0.187 ; \mathrm{P}=0.024)$. There was a positive correlation between weight and Serum level of Vitamin $C(r=-0.174 ; P=0.228)$ and $E(r=-0.177 ; P=0.219)$ but was not significant. The height of the respondents showed a negative correlation between Vitamin $\mathrm{C}(\mathrm{r}=-$ $0.060 ; \mathrm{P}=0.680)$ and $\mathrm{E}(\mathrm{r}=-0.083 ; \mathrm{P}=0.567)$ level, but was not significant.

Table 3: Show Correlation between Anthropometric Parameters (Age, BMI, Weight, \&Height) of Smokers with their Serum Vitamin C \& E Level.

\begin{tabular}{|c|c|c|c|}
\hline \multicolumn{2}{|c|}{ Anthropometric Parameters (Smokers) } & \multirow{2}{*}{$\frac{\text { Vitamin C Level }}{-0.016}$} & $\begin{array}{c}\text { Vitamin E } \\
\text { Level } \\
\end{array}$ \\
\hline Age (Years) & $\begin{array}{l}\text { Pearson } \\
\text { Correlation }\end{array}$ & & -0.108 \\
\hline \multirow{5}{*}{$\mathrm{BMI}\left(\mathrm{Kg} / \mathrm{M}^{2}\right)$} & Sig. (2-tailed) & 0.913 & 0.456 \\
\hline & $\mathrm{N}$ & 50 & 50 \\
\hline & $\begin{array}{l}\text { Pearson } \\
\text { Correlation }\end{array}$ & 0.345 & 0.187 \\
\hline & Sig. (2-tailed) & $0.014^{*}$ & $0.024 *$ \\
\hline & $\mathrm{N}$ & 50 & 50 \\
\hline \multirow[t]{2}{*}{ Weight (kg) } & $\begin{array}{l}\text { Pearson } \\
\text { Correlation }\end{array}$ & 0.174 & 0.177 \\
\hline & $\begin{array}{l}\text { Sig. (2-tailed) } \\
\mathrm{N}\end{array}$ & $\begin{array}{c}0.228 \\
50\end{array}$ & $\begin{array}{c}0.219 \\
50\end{array}$ \\
\hline \multirow[t]{3}{*}{ Height (M) } & $\begin{array}{l}\text { Pearson } \\
\text { Correlation }\end{array}$ & -0.060 & -0.083 \\
\hline & Sig. (2-tailed) & 0.680 & 0.567 \\
\hline & $\mathrm{N}$ & 50 & 50 \\
\hline
\end{tabular}


**. Correlation is significant at the 0.01 level (2-tailed).
*. Correlation is significant at the 0.05 level (2-tailed).

\section{Discussion}

Smoking has been identified as one of the major risk factors in human diseases such as atherosclerosis and several cancers (Doll et al., 1994; Nagaraj et al., 2014), yet approximately one third of the Western World's adult population continues to smoke (WHO Health for All Database, 2000; NICUS, 2004). In Nigeria, 9,503,400 people are involved in tobacco smoking (WHO, 2005). Among other factors, oxidative stress has been suggested to play an important role as initiator of the pathological conditions resulting from tobacco smoking (Pryor and Stone, 1993; Poulsen et al., 1998; Hirvonen et al., 2000; Genkinger et al., 2004). This study investigated the effect of smoking on vitamin $\mathrm{C}$ and $\mathrm{E}$ level in male cigarette smokers in College of Health Sciences, Nnamdi Azikiwe University, Nnewi Campus, Anambra State.

In this study, the mean serum level of vitamin $C$ was significantly decreased in cigarette smokers when compared with non smokers $(0.82 \pm 0.33$ vs $1.49 \pm 0.25 ; \mathrm{p}=0.000)$. This finding agrees with the study of Fatemeh et al. who carried out a study on the evaluation of salivary catalase, vitamin $\mathrm{C}$ and alpha-amylase in smokers and non-smokers and found a lower vitamin C in smokers than non smokers (Fatemeh et al., 2017). This decrease may be as a result of an increased oxidative stress leading to decreased antioxidants levels in smokers. Again, there may be a poor dietary pattern on the part of cigarette smokers with most of them taking little or no fruits and vegetables rich in antioxidants or even specific antioxidant supplements (Ames 1998; Ames and Gold 1998; Ames and Wakimoto, 2002). Thus, because of the consumption of a diet containing more fat and less fruits and vegetables, smokers have a lower intake of a variety of phytonutrients, compared with nonsmokers (Dallongeville et al., 1998; Marangon et al., 1998a; Ma et al., 2000). Other similar studies did show the depleting effect of cigarette smoking on vitamin C level (Calikoglu et al., 2002; Yokus et al., 2005; Nagaraj et al., 2014).

Interestingly, there was a significant decrease in the mean serum level of Vitamin $\mathrm{E}$ in cigarette smokers

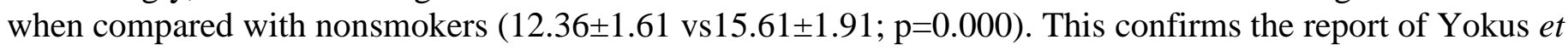
al. who investigated the effects of active and passive smoking on antioxidant enzymes and antioxidant micronutrients and found a significantly lower mean serum vitamin E level in cigarette smokers compared to non smokers (Yokus et al., 2005). This decrease may be due to impaired absorption and bioavilability of vitamin E in smokers. More so, Tobacco smoke contains numerous compounds, many of which are oxidants and prooxidants, capable of producing free radical and enhancing the oxidative stress (van Antverpen et al., 1995; Reilly et al., 1996).

In the present study, the result Shows a statistically Insignificant negative correlation between age and serum level of Vitamin $\mathrm{C}(\mathrm{r}=-0.016 ; \mathrm{P}=0.913)$ and $\mathrm{E}(\mathrm{r}=-0.108 ; \mathrm{P}=0.456)$ in smokers. However, there was a significant positive correlation between $\mathrm{BMI}$ and serum level of Vitamin $\mathrm{C}(\mathrm{r}=0.345 ; \mathrm{P}=0.014)$ and $\mathrm{E}$ $(\mathrm{r}=0.187 ; \mathrm{P}=0.024)$ in cigarette smokers.

\section{Conclusion}

The study shows a significant decrease in the mean serum levels of vitamins $\mathrm{C}$ and $\mathrm{E}$ in cigarette smoker which suggest a depletion of antioxidants status in subjects, thus predisposing them to major risk factors in human diseases such as atherosclerosis and several cancers.

\section{Recommendation}

Based on our findings, we recommend that:

1. Health education strategies should be adopted to enlighten the general public on the deleterious effects of cigarette smoking.

2. Dietary supplementation as well as intake of fruits and vegetables should be ensured by smokers in other to boost their antioxidants status.

3. Further studies should be carried out in view of better understanding the various effects of cigarette smoking on the human body. 


\section{References}

1. Ames B.N., Wakimoto, P. (2002) Are vitamin and mineral deficiencies a major cancer risk? National Review of Cancer; 2:694-704.

2. Ames, B.N. (1998). Micronutrients prevent cancer and delay aging. Toxicological Letters; 102103:5-18.

3. Ames, B.N., Gold, L.S. (1998). The prevention of cancer. Drug Metabolic Review; 30:201-223

4. Calikoglu, M., Tamer, L., Calikoglu, I., Atis, S., Ulubas, B., Ercan, B. (2002). Oxidative stress and products of nitric oxide metabolism in chronic obstructive pulmonary disease and in healthy smokers. Turkish Respiratory Journal; 3(1):24-27.

5. Cross, C.E., Traber, M., Eiserich, J., van deer Vilet., A. (1999). Micronutrient antioxidants and smoking. British Medical Bulletin; 55:691-704.

6. Dallongeville, J., Marecaux, N., Fruchart, J.C., Amouyel, P. (1998). Cigarette smoking is associated with unhealthy patterns of nutrient intake: a meta-analysis. Journal of Nutrition; 128:1450-1457.

7. Dietrich, M., Block, G., Norkus, E.P., Hudes, M., Traber, M.G., Cross, C.E., Packer, L. (2003). Smoking and exposure to environmental tobacco smoke decrease some plasma antioxidants and increase gamma-tocopherol in vivo after adjustment for dietary antioxidant intakes. American Journal of Clinical Nutrition; 77:160-166.

8. Doll, R., Peto, R., Wheatley, K., Gray, R., Sutherland, I. (1994). Mortality in relation to smoking: 40 years' observations on male British doctors. British Medical Journal; 309:901-911.

9. Fatemeh, A., Parisa, F., Mohammad, T.G., Jalal, P. (2017). The evaluation of salivary catalase, vitamin $\mathrm{C}$ and alpha-amylase in smokers and non-smokers: a retrospective cohort study. Journal of Oral Pathology and Medicine; 46(5): 377-380.

10. Genkinger, J.M., Platz, E.A., Hoffman, S.C., Comstock, G.W., Helzlsouer, K.J . (2004). Fruit, vegetable, and antioxidant intake and all-cause, cancer, and cardiovascular disease mortality in a community- dwelling population in Washington County, Maryland. American Journal of Epidemiology; 160:1223-1233.

11. Hirvonen, T., Virtamo, J., Korhonen, P., Albanes, D., Pietinen, P. (2000). Intake ]of flavonoids, carotenoids, vitamins C and E, and risk of stroke in male smokers. Stroke; 31:2301-2306

12. Jadoon, S., Waseem, A., Yaqoob, M., Nabi, A. (2010). Flow injection Spectrophotometric determination of vitamin $\mathrm{E}$ in pharmaceuticals, milk powder and blood serum using potassium ferricyanide-Fe(III) detection system. Chinese Chemical Letters; 21(6) (2010) 712-715.

13. Levine, Robert, J. (2006). Some Recent DevelSopments in the International Guidelines on the Ethics of Research Involving Human Subjects. Annals of the New York Academy of Sciences; 918: 170-178.

14. Lykkesfeldt, J., Christen, S., Wallock, L.M., Chang, H.H., Jacob, R.A., Ames, B.N. (2000). Ascorbate is depleted by smoking and replete by moderate supplementation: a study in male smokers and nonsmokers with matched dietary antioxidant intakes. American Journal of Clinical Nutrition; 71:530-536.

15. Lykkesfeldt, J., Loft, S., Nielsen, J.B., Poulsen, H.E. (1997). Ascorbic acid and dehydroascorbic acid as biomarkers of oxidative stress caused by smoking. American Journal of Clinical Nutrition; 65:959-963.

16. Ma, J., Hampl, J.S., Betts, N.M. (2000). Antioxidant intakes and smoking status: data from the continu- ing survey of food intakes by individuals 1994-1996. American Journal of Clinical Nutrition; 71:774-780.

17. Marangon, K., Herbeth, B., Lecomte, E., Paul-Dauphin, A., Grolier, P., Chancerelle, Y., Artur, Y., Si- est, G. (1998a). Diet, antioxidant status, and smoking habits in French men. American Journal of Clinical Nutrition; 67:231-239.

18. Mosca L, Rubenfire M, Tarshis T, Tsai A, Pearson T (1997) Clinical predictors of oxidized lowdensity lipoprotein in patients with coronary artery disease. Am J American Journal of Cardiology; 80:825-830.

19. Munro LH, Burton G, Kelly FJ (1997) Plasma RRR-alpha-tocopherol concentrations are lower in smokers than in non-smokers after ingestion of a similar oral load of this antioxidant vitamin. Clinical Science (Lond); 92:87-93. 
20. Nagaraj, Priyadarshini M.D., Srikanth. (2014). Effect of cigarette smoking on lipid profile. Journal of biomedical and pharmaceutical research; 3(3):17-20.

21. Nagaraj, Satish, K.D., Prashant, V.P. (2014). Study of serum malondialdehyde and vitamin c in smokers. Journal of Scientific and Innovative Research; 3(6): 569-571.

22. Omaye ST, Turnbull JD, Sauberlich HE. Selected methods for the determination of ascorbic acid in animal cells, tissues and fluids. Methods in Enzymology; 1979;62:3-10.

23. Poulsen, H.E., Loft, S., Prieme, H., Vistisen, K., Lykkesfeldt, J., Nyyssonen, K., Salonen, J.T. (1998). Oxidative DNA damage in vivo: relationship to age, plasma antioxidants, drug metabolism, glutathione- S-transferase activity and urinary creatinine excretion. Free Radical Research; 29:565571.

24. Pryor, W.A., Stone, K. (1993). Oxidants in cigarette smoke. Radicals, hydrogen peroxide, peroxynitrate, and peroxynitrite. Annals of New York Academia of Science; 686:12-27.

25. Reilly, M., Delany, N., Lawson, J.A. (1996). Circulation; 94:19-25.

26. Snežana, Bošnjak. (2001). the declaration of Helsinki: The cornerstone of research ethics. Archive of Oncology; 9 (3): 179-84.

27. Strauss, L.H., Scheer, P. (1939). On the influence of nicotine in the determination of vitamin C. Zeitschrift Fur Vitaminforschung; 9:39-48.

28. The Nutrition Information Centre of the University of Stellenbosch (NICUS 2004).Smoking and Vitamin C: Clarifying the concerns. www.sun.ac.za/nicus/. Accessed on $15^{\text {th }}$ May 2017.

29. van Antverpen, V.L., Theron, A.J., Richards, G.A., Steenkamp, K.J., van der Merwe, C.A. (1995). Free Radical Biology and Medicine; 31:935-941.

30. Yokus, B., Mete, N., Cakir, U.D., Toprak, G. (2005). Effects of Active and Passive Smoking On Antioxidant Enzymes and Antioxidant Micronutrients. Biotechnology \& Biotechnological Equipment; pp. 117-123.

31. WHO Health for All Database, Copenhagen, 2000.

32. World Health Organization, (2005).The Role of Health Professionals in Tobacco Control [booklet].

33. Zondervan, K.T., Ocke, M.C., Smit, H.A., Seidell, J.C. (1996). Do dietary and supplementary intakes of antioxidants differ with smoking status? International Journal of Epidemiology; 25:70-79. 